\title{
4 A liberal senate
}

\section{The Danish Landsting of 1849}

\author{
Flemming Juul Christiansen
}

\section{Introduction}

The Danish constitution of 5 June 1849 introduced the bicameral Parliament. Unlike most other smaller constitutional monarchies at the time, the electorate of the Senate in Denmark, or the upper chamber, became as inclusive as that of the lower chamber, allowing 70 per cent of the male population over 30 to vote. This situation persisted until the Senate became more aristocratic after the constitutional revision in 1866. In the Constituent Assembly of 1848-1849, the question of whether to introduce a bi- or unicameral system and the criteria for suffrage and eligibility raised the most discussion. The introduction of bicameralism became a compromise among various factions of the left, centre and right.

This chapter takes up two discussions within the theoretical approach of 'historical institutionalism' in political science and sociology. First, it argues that 'timing' may have mattered greatly in the sense that initial power structures created a 'path dependency' and that this may have affected what happened in 1848 (Pierson \& Skocpol 2002). Second, the chapter takes up the argument suggested by Kaspersen (2004), that the sudden and major change from absolutism to a system with relatively broad representation in Denmark in 1848 was for its time an unintended consequence of warfare. At the time of the abolition of absolutism, Denmark fought an army consisting of forces from the German Confederation and German-oriented inhabitants of the Duchies of Schleswig and Holstein, which belonged to the Danish conglomerate state. The impact of the war will be demonstrated in the second section, when this chapter presents and analyses the discussions in the Constituent Assembly and highlights the time pressure faced by the Assembly because of the ongoing war. Conservatives, inspired by international developments, were in favour of a bicameral system with limited suffrage and a senate that was intended to function as a delaying 'moderate force' (Hjelholt 1949 , p. 105). However, the principles of democracy and nationalism, ignited by the war, gave weight to the liberal demands for a unicameral system in Denmark. As a result, the third and final section of this chapter concludes that the Danish liberal Senate was a wartime compromise between an international trend of senates functioning as chambres de réflexion and revolutionary democratic principles that allowed for universal suffrage in both chambers. 
This chapter mainly utilises secondary literature written by historians who covered the Constitutuent Assembly quite extensively. They had access to the procedures employed by the Assembly, state council and government. Furthermore, this chapter makes use of materials - which have been left to the Danish National Archive - from the constitutional committee, which was in charge of designing a proposal for a new constitution. The studies of the 1849 constitution by politician and historian Niels Neergaard (1854-1936, MP from 1887 to 1890 and 1892 to 1932; PM from 1908 to 1809), his contemporaries and the jubilee publications from 1949 and 1999 were important sources for this chapter on the Danish liberal Senate (Neergaard 1892; Hjelholt 1949; Møller 1949; Thorsen 1953; Bjørn 1999; Knudsen 2001; Bjørn 2003).

\section{Historical background of the Danish monarchy and the events of 1848}

The Danish monarchy of 1848 consisted of four parts: the Danish Kingdom and the Duchies of Schleswig, Holstein and Lauenburg, all of which had the king of Denmark as their head. Iceland, the Faroe Islands and Greenland also belonged to the Kingdom of Denmark. Attached to the Kingdom of Norway, they became part of the Danish-Norwegian Union from 1380 to 1814. The Treaty of Kiel, 1814, then transferred them to Denmark rather than to the Swedish-Norwegian Union (1814-1905). The Kingdom also possessed colonies in the West Indies and on the Gold Coast. The Kingdom of Denmark traces its history back to at least the tenth century. Holstein and Lauenburg were completely German-speaking areas, and both were members of the German Confederation established after the Treaty of Vienna, 1815. Schleswig was originally a Danish fiefdom, but for centuries it had had German as its administrative language, just like Holstein. In the early nineteenth century, Danish was the language spoken by the people and the language used in church in the Northern part; German, in the Southern part (Bijleveld 2008).

As in other parts of Europe after the Napoleonic Wars, nationalist and liberal sentiments inside the monarchy strengthened after 1815 and during the 1830s and 1840 s in particular. Schleswig was the apple of discord. Both sides in the conflict rejected a division, wanting all of Schleswig. The goal of the Danish nationalists was a united Danish national state, including all of Schleswig, under a free constitution. The German-minded nationalists in Schleswig and Holstein wanted a joint Schleswig-Holstein under a free constitution, with Schleswig admitted into the German Confederation (Friisberg 1974). Furthermore, they pointed at a declaration dating from 1460 - the Ribe letter - issued by King Christian I of Denmark, in which he promised the nobility of Holstein to never separate Schleswig and Holstein. To complicate these matters further, it became likely during the 1840s that the male line of the Danish Oldenburg dynasty, which had reigned since 1448, would end since the crown prince was twice divorced and childless. It was not clear whether the same succession rights of the Duchies also applied to the Kingdom. 
By the beginning of 1848, the Danish monarchy was still absolutist, as it had been since 1660 . In the first half of the nineteenth century, Denmark was a state run largely by a bureaucracy based on the rule of law and with civil servants largely appointed by merit. Nevertheless, all authority originated from the powers of the king. The liberal sentiments of the time desired a constitution to limit the power of the king and to guarantee the rights and representation of the citizens. King Frederik VI (1768-1839; reg. 1784-1839, crown prince regent until 1808) had passed liberal reforms in his youth that freed the peasantry from adscription. Yet in the later years of his long rule, he and the civil servants around him had become resistant to change.

Despite the king's reluctance towards reforms, the liberals' demands were met to a certain extent with the 1833 installation of 'consultative provincial assemblies of estates' for the different parts of the monarchy: two for the Danish Kingdom, one for Schleswig and one for Holstein and Lauenburg. These estates could only give advice to the King. Their electorate was about 2.8 per cent of adult males (Engelstoft \& Wendt 1934). Intended to put a brake on liberal demands, the estates turned out to stimulate political debate and contributed to political involvement of many citizens across the country. The king and his main advisors were primarily concerned that more freedom would engender nationalism and endanger the unity of the remaining parts of the monarchy. After losing Norway in 1814, the government was primarily concerned with keeping the conglomerate state intact.

With the death of Frederik VI in 1839, the liberals had high expectations for his cousin, Christian VIII (1784-1848, ruling from 1839), who in his youth had ruled as the constitutional king of Norway for a few months in 1814 and was generally considered a progressive figure. Yet the new king kept many of his predecessor's advisers and refused to give the people a free constitution. Meanwhile, antagonism grew in Schleswig. In 1840, Christian VIII ordered Danish to be the language of administration in those parts of Schleswig where it was already used in schools and churches. He also declared that the same succession rights of the Kingdom applied to the Duchies (where women could inherit the throne in the absence of any direct male line from Frederik III), hoping to retain the monarchy for his dynastic successors. German nationalists contested this, arguing for the right of succession in the Duchies to belong to a pure male line going back all the way to Christian I, hoping for a successor who would be more sympathetic to their cause than the king of Denmark. When Christian VIII suddenly fell ill and died on 20 January 1848, he advised, from his deathbed, his politically inexperienced son, Frederik VII (1808-1863, ruling from 1848), to establish a free constitution and to find new advisers (Bjørn 1999).

Soon, on 28 January, the king publicly announced his intention to give up absolute rule. He invited representatives from the estates of the Kingdom and the Duchies to discuss a possible constitution with him, and it soon looked as if a compromise was within reach (Bjørn 1999). Subsequently, external events completely took over this process. The 1848 February Revolution in Paris ignited liberal and national sentiments across Europe, not only in Vienna and Berlin - the main cities of the German Confederation - but also in Copenhagen (Denmark) and 
Kiel (Holstein). There, citizens met and made proclamations. On 18 March 1848, a delegation from Kiel headed to Copenhagen in order to prevent the Danish liberals from having their demands realised. Upon their arrival, they were informed that the king had dismissed the government (Friisberg 1974). A new government was formed with representatives from all of the dominant political camps: conservatives, national liberals and 'friends of the peasants' (Bondevennerne). The king declared he would no longer rule as an absolute monarch; instead, he would act on the advice of his new ministers, which predominantly supported the nationalist Danish cause (Bjørn 1999).

The response of the new government to the delegation from Kiel was to acknowledge the demand for a free constitution for Holstein only. The Duchy of Schleswig was to be closely connected to or even incorporated into the Danish Kingdom. When news about the new government in Copenhagen reached the Duchies, a rebellion broke out in Holstein and parts of Schleswig. The Danish Kingdom soon mobilised an army based on conscription, and the First Schleswig War (1848-1851) followed.

\section{Decision to elect a Constituent Assembly}

The new government in Copenhagen promised the people a new constitution. Since the king still formally held absolute power, it would have been possible to issue a constitution in his name. The government, however, wanted to anchor the new freedoms in 'the people' more than in the 'grace' of the king (Møller 1949, p. 68). Therefore, it opted to have a Constituent Assembly design a constitution for the king and the government to ratify. Next, the government had to decide on the electorate of the Constituent Assembly. In 1848, the minister of education and church affairs (1848), Ditlev Gothard Monrad (1811-1887) was most influential, arguing in favour of extended suffrage, thus avoiding the division of the nation into voters and non-voters (Møller 1949). His view prevailed, and the king agreed to grant the right to vote to all adult men above 30 , with certain disqualifying exceptions, such as the non-possession of a household - i.e. servants, prisoners or disempowered individuals. These provisions would allow approximately 70 per cent of men above the age of 30 to vote. About one-third of the voters did cast a vote for the Constitutional Assembly (Neergaard 1892). Men above 25 were eligible for election. The conservative minister of the navy (1848-1850), Christian Christoffer Zahrtmann (1793-1853), argued that 'the intelligent and conservative' should be allotted a considerable share (Thorsen 1967). The government united on the compromise that the king - now acting on the advice of the government was to appoint one-quarter of the Assembly to compensate for the effect of the extended suffrage (Bjørn 1999). The appointments by the king should 'calm and dampen [. . .] overly hasty decisions resulting from general suffrage' (Neergaard 1892). Although the Constituent Assembly became unicameral, similar arguments later became important for the establishment of the Senate in Denmark.

The proposal of the government as to elections for the Constituent Assembly received the support of the two consultative provincial estate assemblies within 
the Kingdom. This was the time of the 'spirit of 48', in which a patriotic and democratic mood of equality prevailed (Bjørn 1999; Neergaard 1892). The connotation of the term 'democracy' changed from negative to positive at this point (Nygaard 2011). As soldiers and the common man had shown so much courage on the battlefield, opposition against a broader franchise disappeared (Neergaard 1892). Rather, there was some opposition towards the appointments to be made by the king since they were believed to demonstrate a lack of confidence in the will of the common people (Neergaard 1892). The electoral law came into force in July 1848, and the elections took place on 5 October 1848 in 114 single-member districts, each contributing about 12,000 voters (Engelstoft 1949).

\section{The factions in the Constituent Assembly}

The candidates for the Assembly did not represent political parties in the modern sense of the word (Thorsen 1953). Historians do, however, identify three broader factions among the candidates, as they do later within the Constituent Assembly and subsequently in Parliament - conservatives, national liberals and 'friends of the peasants', which were at the time already labelled as right, centre and left. The conservatives favoured a bicameral system with a moderating senate appointed either by the king or through very limited suffrage. The conservatives found their supporters among civil servants and urban citizens, in particular of the older generation, and from large estate owners and the aristocracy (Høgh 1972). The national liberals supported a liberal constitution with guaranteed freedoms but were divided over the degree of the extension of suffrage and whether to have two chambers or one. This party was largely inspired by national and liberal movements elsewhere in Europe at the time (Salvadori 1972). It was supported by intellectual urban elites and citizens - the younger generation in particular. This movement was dominated by a group of men born around 1810, several of whom went on to obtain important positions in Parliament and in government and as civil servants and who strongly affected Danish politics until 1864. During the 1840 s, they had advocated the reforms and nationalist policies that prevailed after the governmental shift in 1848 .

Established only in 1846, the Society for the Friends of the Peasants had amassed almost 10,000 members by the summer of 1848 (Neergaard 1892). The Danish peasantry, which made up by far the largest part of the population, had made great advances since major reforms at the end of the eighteenth century by gradually replacing sharecropping and introducing better education. A peasantoriented national ideology arose around a number of figures, in particular N.F.S. Grundtvig (1783-1872), a Lutheran pastor, thinker and author who called for a political - national, democratic and religious - awakening among the peasantry (Korsgaard 2014). Politically, the 'friends of the peasants' were in favour of extended voting rights and a unicameral system with no appointment of representatives by the king. It had its strongest support in the peasantry, but some of its candidates were academics. The older and the younger generations of political actors were divided between Danish nationalists (national liberals 
and a few conservatives and 'friends of the peasants', as well as the king, Frederik VII) and anti-nationalists (most conservatives and 'fiends of the peasants') (Vammen 2011).

During the electoral campaign in the summer of 1848, the question of the extension of suffrage was most important, with the question of a uni- or bicameral system receiving much less attention (Neergaard 1892). The political tendencies of the 114 elected and thirty-eight appointed members of the Constituent Assembly have been assessed in various different ways since they did not vote consistently across matters (Neergaard 1892; Jensen 1915; Elberling 1949; Olsen 1972). According to Neergaard, thirty-three right-wing members (conservatives), thirty-two centrists (national liberals) and forty-four left-wingers ('friends of the peasants') were elected. The king appointed five members to represent Iceland and one to represent the Faroe Islands (Neergaard 1892; Bjørn 1999). After the appointments by the king, the Assembly developed a slightly more conservative bent, with the numbers changing to fifty-four, forty-three and forty-seven respectively. Roughly speaking, however, each political tendency accounted for onethird of the members. Of the elected members, fifty-seven were civil servants, thirty-eight were peasants, seventeen were trade and craftsmen, fifteen came from larger estates and the rest came from other trades (Bjørn 1999). Compared with the population at large, the civil servants, who had played the dominant role in the government during the final decades of absolutism, were still clearly overrepresented but now had to share power. Despite the underrepresentation of the peasants, they were now much better represented than before.

At the opening meeting of the Constituent Assembly on 23 October 1848, the government presented its proposal for a constitution (reprinted by Bjørn 1999). The proposal suggested two chambers, both directly elected by 'the people'. The suffrage for both chambers would include anyone above the age of 30 under the same rules that had applied to the Constituent Assembly election. The Senate (Landsting) would comprise one-fourth of the members of the lower chamber (Folketing). However, to be eligible for the Senate, one had to be at least 40 . The proposed minimum age for members of the lower chamber was 25 , which was below the voting age. Members of the Senate would not receive an allowance, unlike the members of the lower chamber. The members of the Senate were to be elected for eight years, and every fourth year, half of them would run for election again. The members of the lower chamber would be elected for a term of four years.

This proposal was issued by a committee consisting of three ministers. The government had discussed the draft during several meetings. Monrad - who came to write the draft in cooperation with Orla Lehmann (1810-1870; minister without portfolio 1848) - had studied the Belgian constitution of 1831 and the Norwegian constitution of 1814 and reused formulations found in them (Møller 1949). Belgium had a bicameral parliament and required that voters pay a certain amount of taxes and another, higher amount to be eligible for election (cf. Witte, this volume). Norway elected a unicameral parliament that divided itself into two chambers afterwards (cf. Smith, E., this volume). From its first draft of 26 June, 
the preparatory cabinet committee worked with a bicameral system. It argued that a senate could become 'a regulator to prevent overly hasty action', i.e. it should become a chambre de réflexion. In the internal proceedings from the drafting committee, we see that Monrad had argued for a very low tax requirement. Nevertheless, he and other ministers were also concerned about 'the danger of communism' (Møller 1949, pp. 59-63; Thorsen 1967, p. 81; cf. Nygaard 2011).

There was internal disagreement between the ministers in the cabinet as to whether Denmark should have one or two chambers and whether they should be subject to dissolution or not. A. F. Tscherning (1795-1874, minister of war 1848), the most left-leaning member of the government, did not think a senate would make much of a difference. However, he was opposed by a number of more conservative ministers. The head of government, Adam Wilhelm Moltke (17851864, prime minister 1848-1852), was concerned that the moderating effect of the proposed senate would be weakened, and he later argued for a lower chamber of 'personalities' and a senate of 'property' (Møller 1949, p. 78). It culminated in a vote in the state council, with Monrad's point of view prevailing. As summarised by Møller (1949, p. 80), his idea was for both 'chambers to originate directly from the people but with different characters, in all aspects equal, but also equally subject to dissolution'.

The constitutional proposal of the government, including a rather liberal senate, formed the foundation for the negotiations about the constitution that began within the Constituent Assembly from October 1848 to May 1849. The European context for the work changed during that period. While revolutionary euphoria characterised the early months of 1848 , reactionary forces had suppressed the revolutions in Vienna and Berlin by the end of the year. In Copenhagen, the 'March ministry' broke down over the issue of how to handle Schleswig. In November, a new government, still headed by Moltke, featured more conservatives and still included several national liberals - but no one from the left. In August 1848, the war over Schleswig came to a truce, and peace negotiations followed in London. By the end of February, negotiations in London broke down and war resumed in April 1849.

These events did not seem to have profoundly affected the negotiations concerning the constitution, but they did turn time into a factor. Because of the generally more anti-revolutionary mood, conservatives believed that as time passed by, their cause would benefit. A peace deal involving foreign powers, in particular, would restrain the calls for democracy. At an early stage, they proposed to abandon the work of the Assembly, arguing to halt negotiations concerning a constitution as long as the Schleswig question could not be settled due to the war, but this proposal was defeated (forty-seven in favour, one hundred against). Over the next six months, the Constituent Assembly debated the question of one or two chambers several times, voting on amendments to the proposed constitution regarding the issue of bicameralism. The issue became closely connected with the issue of extended suffrage, which meant that most members of the Assembly now saw it as the most important question. The debate divided the three main factions, with the left supporting unicameralism and extended suffrage and the right supporting 
bicameralism with limited suffrage, at least for the Senate, or alternatively one chamber with limited suffrage. The centrists largely supported the proposal of the government, but some were open to restricted voting rights and eligibility out of concern for the level of public education, which was perceived to be insufficient, especially among the peasantry (Jørgensen 1968).

The deliberations in the Assembly proceeded as follows. In October 1848, the Assembly divided itself by lot into five groups that, in December 1848, each elected two members to a 'Constitutional Committee'. Together with seven members elected by the Assembly at large, the Committee came to consist of seventeen members. This procedure benefitted centrist members, and ultimately it consisted of nine centrists, four conservatives and four left wing members. The Committee worked until the end of February without reaching an agreement. It ended up with six different minority reports on its composition, i.e. voting rights and eligibility as well as several proposals on whether to have a senate or not. (Engelstoft 1949; Bjørn 1999). These reports reflected positions from the left of the political spectrum to the right. The largest minority supported the proposal of the government. Yet the result that passed on 25 May 1849 was influenced by ideas in two of the other minority reports about more conservative eligibility criteria for the Senate.

Following the presentation of the six minority reports, debates, negotiations and coalition-building emerged within the Constituent Assembly. Again, the issue of bicameralism was linked to the issue of suffrage. The conservative faction decided, for tactical reasons, to support a unicameral solution. If this proposal passed with support from the left, the idea was that the government and the centrists would have to delay their work on the constitution for some time, at least until there was a peace settlement. Meanwhile, two centrist representatives Mads Pagh Bruun (1809-1884) and Christian Magdalus Jespersen (1809-1873), both members of the Constituent Assembly - proposed an amendment suggesting an indirectly elected senate (voters selecting electors in broad constituencies who then elected the senate members). Over time, the Senate would be elected by the municipalities. Until then, the franchise would be similar to the lower chamber but with high eligibility requirements: an income of 1,200 Rigsbankdaler or a tax payment of 200 Rigsbankdaler annually and an age requirement of 40 .

The new minister of culture and education, Johan Nicolai Madvig (1804-1886, minister 1848-1851), a centrist with conservative leanings, wanted more 'conservative guarantees' than those that were offered in the government's original proposal and urged the conservatives to give up their unicameral proposal. A vote was taken: twenty-eight in favour of one chamber, 112 against. Next, there was a vote on the Bruun and Jespersen amendment, which passed by a narrow margin of sixty-eight votes (conservatives and some centrists) to sixty-six (other centrists and left-wing members). With such divided support in the Constituent Assembly, the government declared that it would not recommend that the king ratify the constitution. Through Madvig, it stated that such a narrow majority could be 'coincidental' and a result of the 'moods of the moment' and that there might be 'strength' and 'insight' in such a large minority. This gave the conservatives new hopes to delay and win time. Because of the pressure, the left-leaning representatives 
changed their mind and decided to support the Bruun-Rasmussen amendment, making it clear that a broad majority for a new constitution was within reach. In a new vote, the amendment passed 127 to thirteen, with broad support from members of all three political leanings.

With regard to indirect election and eligibility criteria, the amendment that passed was more conservative than the government's original proposal and more in line with the new centrist-conservative government. The outcome was that an estimated 4 per cent of the electorate could be elected to the Senate (Nygaard 2017), but extended suffrage remained in place for the Senate without tax requirements. The final proposal for a new constitution came to a vote on 25 May 1849 and passed with 119 votes against four. On 3 June, the government unanimously recommended the proposal to the king, who signed it 5 June 1849 . This date is now constitution Day in Denmark.

\section{What followed? The end of the war and its effect on the Constitution}

After the great power of Russia compelled the forces of the German Confederation to retreat, Denmark defeated the Schleswig-Holstein separatists, which ended the First Schleswig War in 1851. A peace treaty was hard to reach because of incompatible demands on both sides. Furthermore, the European great powers insisted on the unity of the Danish monarchy, secured in a constitutional union between the Kingdom and the three Duchies. This required the settlement of the question concerning the succession of the Danish king. Russia, in particular, was not satisfied with the Danish democratic 'experiment'. During the peace negotiations in London in 1852, Prince Christian of Glücksburg (later King Christian IX 1818-1906, ruling from 1863) was elected successor. Furthermore, there was an explicit ban against the incorporation of Schleswig into the Danish Kingdom and the obligation to design a constitution for the conglomerate Kingdom. These decisions, laid down in the London Protocol of 1852, were labelled in Denmark as 'the European necessity', and conservative governments ruling until 1854 aimed to follow the decisions but met with resistance from the national liberals.

The London Protocol aimed at solving the dynastic claims of all parties but offered no solution to the nationalist sentiments that had caused the conflict. Therefore, none of the parties involved were satisfied with the peace treaty. A new 'joint constitution' came into effect in 1855 for matters of the conglomerate Kingdom defence, monarchy, foreign affairs - leaving the constitution of June 1849 intact for interior matters. The new constitution operated with a 'Council of the Realm' elected on terms much more favourable to the conservatives (of the eighty members, twenty were appointed by the king, thirty were elected by estates and thirty were elected by the same electorate as that which elected the lower chamber and the Senate) - with an early version of proportional representation. It was a unicameral body with representatives from both the Kingdom and the Duchies. It was boycotted by German-speaking representatives, however, and in 1857 the German Confederation decided that it did not live up to the London Protocol (Bjørn 2003). 
Vammen (2011) argues that the state became 'empty' during those years, since the dominant political faction of the national liberals was unwilling to adopt the policy required by the international powers in the peace treaty of 1852 .

The German nationalists resented pro-Danish language policies in Schleswig put in place by the national liberal governments in power from 1854 until 1864. In 1863, the government saw an opportunity to pass a constitution that covered only the joint areas of concern in the Danish Kingdom and the Duchy of Schleswig. This constitution was based on a bicameral system with a senate that had about one-fifth of its members appointed by the king, while all other members were elected according to the 1849 constitution. As such, this was a rather liberal senate, and generally speaking, the joint constitution was also more liberal than its 1855 counterpart. This constitution passed in the end of 1863 and awaited only the signature of the king, who suddenly fell ill and died.

Unlike his predecessor, the new king, Christian IX, was a staunch supporter of a united Kingdom, yet he gave into the pressure from the government to sign the new constitution for Denmark and Schleswig. The incorporation of Schleswig into a constitution together with the Kingdom of Denmark was a blatant violation of the London Protocol of 1852, providing Austria and Prussia with a casus belli. They invaded the Duchies and much of Jutland in 1864 and defeated the Danish army. The peace between Denmark, Prussia and Austria signed in Vienna in 1864 saw the Danish Kingdom lose all the Duchies. This left Denmark as a small country with two constitutions: the one from 1849 for interior matters and the one from 1863 for those matters that concerned the Kingdom as a whole. It also had four Chambers, two for each structure. In 1866, a new constitution replaced this system. The 1864 defeat was blamed heavily on the national liberals and democratic rule. Negotiations resulted in a new constitution with a largely unchanged lower house but a profoundly more conservative Senate. Again, the Senate had fallen victim to the need to reach a compromise.

\section{Discussion}

The liberal Senate (1848-1866) was the result of a compromise. The government and the Constituent Assembly believed that 'an honest senate' should be a moderating force (Hjelholt 1949, p. 105). Did the Senate live up to these intentions? Testimony from members of the two new Chambers shows that the lower chamber soon became the more important since this was where the government usually introduced bills, and the meetings of the Senate were fewer and shorter (Hjelholt 1949). Peter Christian Kierkegaard (1805-1888, member of the Senate 1849-1853 and brother of the famous philosopher Søren Kierkegaard) stated that the Senate only occasionally had a moderating influence and that the debates there were less cheerful (Hjelholt 1949). The approximate size of the party factions in the lower chamber and the Senate 1849-1866 is presented in Table 4.1. Not all members are easy to allocate to particular party factions, so the numbers should be read with much caution. Nevertheless, they do indicate that the Senate had a more conservative bent - an observation that has also been made in qualitative terms 
Table 4.1 Approximate party positions in the Danish Parliament, 1849-1866

\begin{tabular}{lllrc}
\hline Lower House & Left & Centre & Right & Others \\
\hline 1849 & 45 & 42 & 8 & 6 \\
1852 & 40 & 47 & 9 & 5 \\
1855 & 54 & 23 & 21 & 3 \\
1858 & $15+41=56$ & 20 & 16 & 9 \\
1861 & 34 & 46 & 5 & 9 \\
1864 & 39 & 40 & 11 & 11 \\
1865 & $5+17+20=42$ & $20+20=40$ & 4 & 5 \\
1866, June & $15+13+30=58$ & $20+10=30$ & 13 & 0 \\
\hline
\end{tabular}

Source: 101 members in total (three elections in 1853 and 1854 omitted)

\begin{tabular}{lllll}
\hline Senate & Left & Centre & Right & Others \\
\hline 1849 & 13 & 13 & 26 & \\
1853 & 14 & 11 & 27 & \\
1855 & 13 & 15 & 23 & 1 \\
1859 & 20 & 14 & 17 & 1 \\
1863 & 23 & 14 & 14 & 1 \\
1866, May & 21 & 11 & 19 & 1 \\
\hline
\end{tabular}

Source: Fifty-two members in total

by Hjelholt (1949). The numbers also demonstrate that the left grew stronger over time, most likely as a consequence of higher turnout. This was due primarily to the peasantry, who were initially more likely to vote for the lower chamber but later started voting for the Senate too.

The Danish constitution of 1849 introduced some democratic and many liberal components, including broad, almost general suffrage for men above the age of 30 for both houses. This analysis shows that the constitution was the result of a compromise between the main factions of the left, centre and right of the political spectrum, which represented different attitudes towards democracy, ranging from support to moderate support to criticism. A liberal senate made sense - the centre and the left supported extended suffrage, and the centre and the right supported bicameralism, the former wanting a moderating and delaying body and the latter preferring a system with a narrower electorate. Even when the external conditions changed throughout the course of 1848, with the major European powers moving away from national revolution and democracy, the Constituent Assembly remained in place and finished its task of making a new constitution that was still inspired by the revolutionary moods of 1848 . On the one hand, these external changes encouraged the conservatives to attempt various delaying tactics. Yet it also spurred the left to accept a compromise that moved the government's original proposal in a slightly more conservative direction. Otherwise, the renewed reaction in Europe would mean that there would most likely not have been a new 
constitution for quite some time to come (Neergaard 1892). The external conditions meant that the right and the left operated under different time horizons, and this difference helped them strike a compromise.

The composition of the Constituent Assembly was not exogenous to the process. It was crucial for the process and the outcome that the Constituent Assembly was elected by a relatively broad electorate while being supplemented with royal appointments, and the left managed to get a significant number of members elected who supported a greater degree of democracy. One wonders why the government opted for such extended suffrage in the first place. The analysis here points to the strong perception that, despite a revolutionary mood throughout Europe that led to uprisings in Paris and Kiel and a diffuse fear of 'communism', the Danes had shown that their national character was of a moderate nature. With conscription in place to help the country fight a war for the nationalist cause, it became harder to deny the people the right to vote. To that extent, this chapter confirms the argument put forward by Lars Bo Kaspersen (2004), but this contribution also highlights another dimension. The acceptance of extended suffrage depended on the introduction of a senate, which was primarily the result of a compromise between the three factions within the Constituent Assembly. Broader changes in society, such as the emancipation of the bourgeoisie, the mobilisation of the farmers and the increasing strength of reactionary forces in Europe, played significant roles as well (cf. Vammen 2011).

The constitutional process of 1848-1849 came too late to solve the conflict between Danish and German nationalists inside the Kingdom. The constitution covered only the Kingdom proper and did not consider having a senate for the Kingdom as a whole by giving the Duchies and/or the German-speaking minority a place in the Senate. Such a proposal would have had the support of most conservatives, who defended the interests of the Kingdom as a whole. The events of March 1848 meant the end of such a senate and postponed a solution until after a peace settlement. As we have seen, no such solution was ever accepted by both Danish and German speakers between 1852 and the next war, in 1864. Such a policy became more typical for the twentieth and the twenty-first centuries than for the nineteenth century - in line with the government's current attempts to unify the Danish regions instead of leaving room for regionalism (cf. Frandsen 2013).

\section{Conclusion}

Extended suffrage gave the left, which represented the peasants, a chance to elect a high number of representatives to the Constituent Assembly, where this group managed to act as a disciplined unit with a clear idea about its goals. Without prior organisation in the Society for the Friends of the Peasants, the left would, most likely, not have become such a strong force in the Constituent Assembly. Although its leaders did not play as active a role in the negotiations as the national liberals and conservatives, they were able to differentiate between their primary aim, general suffrage, and their secondary aim, unicameralism. They did not acquiesce when the conservatives offered unicameralism, knowing that it could come at the 
expense of extended voting rights. In the end, they delivered enough votes for the compromise to gain a broad majority and persuade the government to recommend the new constitution to the king.

Viewed from a North Atlantic perspective, the 1848-1849 crisis of the Danish realm made it possible for groups that normally would have been excluded to participate in political deliberations, resulting in a liberal constitution in which the principle of extended suffrage and the presence of a senate functioned as the main bargaining chips. The establishment of the Danish Senate was a result of a compromise and was intended to function as a counterweight to extended suffrage. Nevertheless, compared with the senates in the North Atlantic region that were established somewhat earlier (e.g. in Belgium) or later in the 1860s (e.g. Sweden, Canada and Denmark), it was still relatively liberal. The compromise reflected the powers of its time. In that sense, Monrad was right when he responded to fellow minister Tscherning in a state council meeting on April 6, 1848: 'one should [. . .] recall that the constitution of a realm depends on the stars under which it is born' (Møller 1949, p. 67).

\section{References}

Bijleveld, N. (2008), 'Language, national culture and the clergy in nineteenth-century Denmark', in: Broomans, P. et al. (eds.), The Beloved Mothertongue: Ethnolinguistic Nationalism in Small Nations: Inventories and Reflections (Leuven: Peeters Publishers), pp. 93-107.

Bjørn, C. (1999), Kampen om grundloven (Copenhagen: Fremad).

Bjørn, C. (2003), '1814-64', in: Bjørn, C. and Due-Nielsen, C. (eds.), Fra helstat til nationalstat 1814-1914 (Copenhagen: Gyldendal), pp. 13-263.

Elberling, V. (1949), Rigsdagens Medlemmer gennem 100 Aar (Copenhagen: J.H. Schultz Forlag).

Engelstoft, P. (1949), 'Den grundlovsgivende rigsforsamling', in: Fabricius, K. et al. (eds.), Den Danske Rigsdag 1849-1949, Vol. 1 (Copenhagen: J.H. Schultz Forlag), pp. 11-40.

Engelstoft, P. and Wendt, F.W. (1934), Haandbog i Danmarks politiske historie. Fra freden $i$ Kiel til vore dage (Copenhagen: Gyldendalske Boghandel).

Frandsen, S.B. (2013), 'Some Reflections on Schleswig and Holstein as contested regions', in: Bregnsbo, M. and Jensen, K.V. (eds.), Schleswig-Holstein - Contested Region(s) Through History (Odense: Syddansk Universitetsforlag), pp. 15-24.

Friisberg, C. (1974), På vej mod et demokrati. Fra junigrundloven 1849 til junigrundloven 1915 (Copenhagen: Fremad 1974).

Hjelholt, H. (1949), 'Under junigrundloven 1849-1966', in: Fabricius, K. et al. (eds.), Den Danske Rigsdag 1849-1949, Vol. 1 (Copenhagen: J.H. Schultz Forlag), pp. 95-340.

Høgh, E. (1972), Vcelgeradfcerd i Danmark 1849-1901. En politisk sociologisk analyse (Copenhagen: Jørgen Paludans Forlag).

Jensen, J.P. (1915), Valgene til Rigsdagen 1848-1915. En historisk-statistisk Fremstilling (Roskilde: Roskilde Dagblads Trykkeri).

Jørgensen, E.S. (1968), 'Partier og partimodsætninger 1848-1864', in: Salomonssen, P. (ed.), Den politiske magtkamp 1866-1901 (Copenhagen: Jørgen Paludans Forlag), pp. 11-24. 
Kaspersen, L.B. (2004), 'How Denmark became democratic: The impact of warfare and military reforms', Acta Sociologica 47(1), pp. 71-89.

Knudsen, T. (2001), Da demokrati blev til folkestyre. Dansk demokratihistorie, Vol. 1 (Copenhagen: Akademisk Forlag).

Korsgaard, O. (2014), N.F.S. Grundtvig as a Political Thinker (Copenhagen: DJØF Publishing).

Møller, J. (1949), 'Forarbejder til grundlovsudkastet', in: Fabricius, K. et al. (eds.), Den Danske Rigsdag 1849-1949, Vol. 1 (Copenhagen: J.H. Schultz Forlag), pp. 41-94.

Neergaard, N. (1892), Under Junigrundloven. En Fremstilling af det danske Folks politiske Historie fra 1848 til 1866. Første bind (Copenhagen: P.G. Philipsens Forlag).

Nygaard, B. (2011), 'Demokratibegrebets gennembrud i Danmark 1848', Historisk Tidsskrift 111(1), pp. 37-73.

Nygaard, B. (2017), Grundloven (Aarhus: Aarhus Universitetsforlag).

Olsen, P.N. (1972), 'At the cradle of a party system: Voting patterns and voting groups in the Danish Constitutional Convention 1848-1849', Scandinavian Political Studies 7, pp. 119-135.

Pierson, P. and Skocpol, T. (2002), 'Historical institutionalism in contemporary political science', in: Katznelson, I. and Milner, H.V. (eds.), Political Science: The State of the Discipline (New York: W.W. Norton \& Co.), pp. 693-721.

Salvadori, M. (ed.) (1972), European Liberalism (London: John Wiley \& Sons).

Thorsen, S. (1953), Folkets Veje. Gennem dansk Politik 1849-1949 (Copenhagen: Forlaget Fremad).

Thorsen, S. (1967), De danske ministerier. Et hundrede politisk-historiske biografier (Copenhagen: Pensionsforsikringsanstalten).

Vammen, H. (2011), Den tomme stat. Angst og ansvar i dansk politik 1848-1864 (Copenhagen: Museum Tusculanums Forlag). 
Denmark, including the Duchies of Schleswig and Holstein

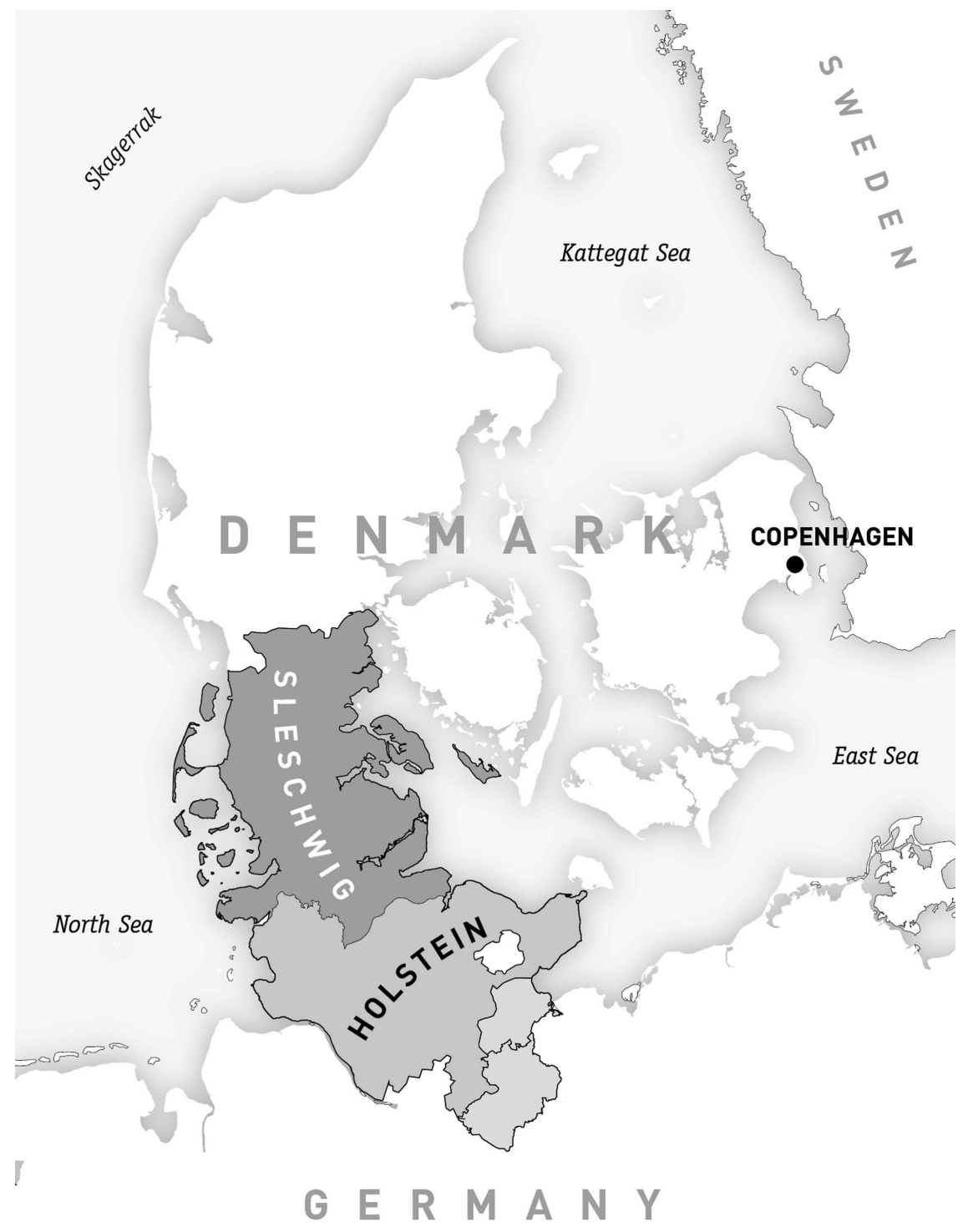

(Bert Brouwenstijn, Vrije Universiteit Amsterdam) 